\title{
Locus of Control in Mexican University Students Comparisons by Gender
}

\author{
Perla Jannet Jurado García, (MP) \\ Julio Cesar Guedea Delgado, (Dr) \\ Leopoldo Ramirez Llanes, (MA) \\ Fernando Mondaca Fernandez, (MC) \\ Elia Veronica Benavides Pando, (Dr) \\ Autonomous University of Chihuahua / México
}

doi: 10.19044/esj.2016.v13n2p235 URL:http://dx.doi.org/10.19044/esj.2016.v13n2p235

\begin{abstract}
The aim of this research was to compare the profiles of locus of control in Mexican university students. The total sample was of 1537 subjects; 820 women and 717 men, with a mean age of 20.38 years (SD = 1.81 ) and 20.78 years ( $S D=1.94)$ respectively. The approach adopted in the research is framed within a quantitative approach with a survey descriptive design. The results of the multivariate analysis of variance, followed by the univariate variance analyzes, are the ones who show higher levels of external locus of control in the factors of luck, political power, destiny and interpersonal relationships, while men report higher levels of locus as luck external control, political power, destination and interpersonal relationships. The differences found between men and women regarding the locus of control, suggest that when designing any intervention that aims to strengthen the internal locus of control will have to take into account the gender variable.
\end{abstract}

Keywords: Locus of Control, Gender Differences, Perceptions, Attribution Styles

\section{Introduction}

The human being as such, is always in constant search for the causes and the reason for his behavior and that of others (Mkumbo and Amani, 2012). Throughout life there are positive and negative events, also called successes or failures, the result of these events can be classified on one hand as internal when we believe they are depending on our behavior or personality, and on the other hand as external when we consider that the causes come from luck or the decision of someone else (Mayoral, Gangloff 
and Romero, 2009), Rotter described this distinction between internal or external control some decades ago and he called it locus of control. It is noteworthy that in the literature often the terms locus of control and attribution styles are used as equivalent (Visdómine-Lozano and Luciano, 2006).

In several studies it has been found that gender makes a significant contribution in predicting attribution styles or locus of control. On the one hand some authors claim that women are more likely to have an internal locus of control compared to men (Camgoz, Tektas and Metin, 2008; Rodríguez-Marín and English, 2011; Suarez-Alvarez Pedrosa, García-Cueto and Muñiz, 2016). In contrast, other authors state that women perceive the consequences of their behaviors depend on factors outside their control such as luck, destiny or the participation of others, ie, their locus is external, while men manifest an internal locus of control (Brenlla and Vazquez, 2010; Bulut, Serin and Şahin, 2010; Duran-Aponte and Pujol, 2012; Montes-Hidalgo and Thomas-Saturday, 2016 and Mohsin Zaidi, 2013). Although some have reported there are no differences between internal or external locus of control by gender (Sagone and De Caroli, 2014).

Rotter characterized the locus of control as a unidimensional construct, but Lefcourt, Von Baeyer, Ware and Cox (1979) they characterized it as multidimensional, and like this has been used in many investigations, however, the unidimensionality of locus of control has been very questioned (Brenlla and Vazquez, 2010; Ferrando, Demestre, Anguiano-Carrasco and Chico, 2011;. Suarez-Alvarez et al, 2016), although in its review Mayora-Pernia and Fernandez (2015) state that the locus of control has developed form being dichotomous to multidimensional.

On the other hand, based on the meta- analysis reported by Richardson, Abraham and Bond (2012) on the psychological correlates and the academic achievement in college students has shown that attributional styles have an effect in the academic performance, where some students tend to explain poor grades based on their own deficiencies, ie, due to internal causes such as lack of effort or skill, while others attribute it to external causes such as bad luck or inadequate teaching.

Also according to Salvador and Mayoral (2011) these interpretations that are made about the behaviors affect the self-image and consequently the motivation and behavior of people (Salvador Mayoral, 2011; Sanjuan and Magallares, 2006).

From all the above hence the importance of research on locus of control, this study attempts to determine the differences and similarities between men and women Mexican university students regarding the perception of their locus of control; taking into account its importance for psychological well-being and performance of a person. Consequently this 
research aims, as an applied research, provide information that translates into a higher quality educational practice in the context of attention to diversity; contributing to pedagogical knowledge that clarifies the factors that make a model of integral human development.

\section{Methods}

\section{Participants}

Were 1537 subjects in the study, 820 women and 717 men, all students of the degrees offered at the Faculty of Physical Culture (FCCF) of the Autonomous University of Chihuahua. The age of women ranged between 18 and 26 years, with a mean of 20.38 and a standard deviation of 1.81 years and the age of men between 18 and 26 years, with a mean of 20.78 and a standard deviation of 1.94 years.

The sample was obtained by a convenience sample, trying to cover the representation of the different semesters of both degrees

\section{Instrument}

Locus of Control Scale by Rotter, Spanish version adapted by Bibiano, Ornelas, Aguirre and Rodriguez-Villalobos (2016) is a Likert questionnaire, assisted by computer, which consists of 12 items grouped in four dimensions or subscales: (1) luck, consisting of four items with statements like "we could often decide what to do simply by flipping a coin," (2) political power, composed of three items contains items with statements such as "it is difficult for people to have too much control over what politicians do" (3) Destiny, consisting of two items ("I have often noticed that what has to happen will happen" and "in the long run, the bad that happens to us is compensated by the good that happens to us") and (4) interpersonal relationships composed of three items, with statements like "no matter what you do, there will always be someone who does not like you."

From two conflicting claims the respondent chooses the statement that best reflects his opinion. Higher scores indicate higher levels of external locus of control (Figure 1). 
Select and drag to the yellow box

the phrase that best reflects your opinion or judgement

SENTENCE \#1: No matter how hard you try, some people just don't like you.

SENTENCE \#2: People who can't get others to like them don't understand how to get along with others.
1

1

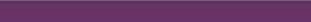

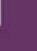


found in the first screens; before the first instrument item. At the end of the session they were thanked for their participation.

Once the instrument was applied, data was collected by the results generator module of scales editor, version 2.0 (H. Blanco et al., 2013).

\section{Data analysis}

Descriptive statistics (means and standard deviations) for all the variables were calculated. Subsequently, after verifying that the data met the assumptions of parametric statistical analyses, a multiple analysis of variance (MANOVA) followed by analysis of variance of one factor (ANOVA) was used to examine differences between women and men regarding their external locus of control in each of the subscales of the Spanish version of the Locus of Control Scale by Rotter adapted by Bibiano et al. (2016). The effect size was estimated using the eta-squared ( $\eta 2)$. All statistical analyses were performed using the SPSS version 20.0 for Windows (IBM $₫$ SPSS ${ }^{\circledR}$ Statistics 20). The statistical significance level was set at $\mathrm{p}<.05$.

\section{Results}

Table 1 shows the mean values and standard deviations of selfefficacy in the five factors of the AUDIM, also the MANOVA results and the subsequent ANOVAs.

MANOVA results showed global differences statistically significant according to the gender variable in self-concept scores (Wilks $\lambda=.905, \mathrm{p}$ $<.001 ; \eta 2=.095)$.

Subsequently, ANOVAs indicated that, compared to the women students, men students show higher scores in external locus of control in luck $(\mathrm{F}=8.431, \mathrm{p}<.01)$, and lower in Destiny $(\mathrm{F}=102.239, \mathrm{p}<.001)$ and in interpersonal relationships $(\mathrm{F}=58.770, \mathrm{p}<.001)$. While in the subscale of political power no significant differences were found ( $>.05)$.

Table 1. Results of MANOVA and ANOVAs for the gender differences on the four subscales of Locus of Control Scale

\begin{tabular}{cccccc}
\hline & $\begin{array}{c}\text { women } \\
(n=820)\end{array}$ & $\begin{array}{c}\text { men } \\
(n=717)\end{array}$ & $F$ & $p$ & $\eta^{2}$ \\
\hline & & & 40.301 & $<.001$ & .095 \\
1) Luck & $0.67(0.03)$ & $0.81(0.04)$ & 8.431 & $<.01$ & .005 \\
2) Political Power & $1.77(0.04)$ & $1.69(0.04)$ & 2.344 & .126 & .000 \\
3) Destiny & $1.28(0.03)$ & $0.895(0.03)$ & 102.239 & $<.001$ & .062 \\
4) Interpersonal Relationships & $2.04(0.03)$ & $1.68(0.03)$ & 58.770 & $<.001$ & .037 \\
\hline
\end{tabular}

Note. Descriptive values are reported as mean (standard deviation).

\section{Conclusion}

The results show that, even though no significant differences were found between men and women in the political power factor, women are the 
ones who show higher levels of external locus of control in situations related to the destiny and interpersonal relationships, results that are consistent with the reported by Brenlla and Vazquez, 2010; Bulut et al, 2010; Duran-Aponte and Pujol, 2012; Montes-Hidalgo and Thomas-Saturday, 2016 and Mohsin Zaidi, 2013. On another hand, men manifest higher levels of external locus of control as to what related to luck; which is consistent with that reported in other studies (Camgoz, Tektas and Metin, 2008; Rodríguez-Marín and English, 2011; Suarez-Alvarez Pedrosa, García-Cueto and Muñiz, 2016).

The results also suggest that men and women report higher levels of external locus of control concerning interpersonal relationships.

The differences found between men and women regarding their external locus of control also suggest that when designing any intervention that aims to decrease it, the gender variable should be taken into account; however, it is necessary to develop more research in this subject because the issue goes beyond the scope of this research. The importance of more research on this subject in our country is also emphasized.

\section{Acknowledgements}

This study is part of a project funded by the Secretaría de Educación Pública-Subsecretaría de Educación Superior-Dirección General de Educación Superior Universitaria de México [Mexican Ministry of Education-Department of Higher Education-General Directorate of the University Education] (OF-13-6894).

\section{References:}

1. Bibiano, M. A., Ornelas, M., Aguirre, J. F. y Rodríguez-Villalobos, J. M. (2016). Composición Factorial de la Escala de Locus de Control de Rotter en Universitarios Mexicanos. Formación Universitaria, 9(6), xx-xx.

2. Blanco, H., Ornelas, M., Tristán, J. L., Cocca, A., Mayorga-Vega, D., López-Walle, J. y Viciana, J. (2013). Editor for creating and applying computerise surveys. Procedia Social and Behavioral Sciences, 106, 935-940. doi: http://dx.doi.org/10.1016/j.sbspro.2013.12.105

3. Brenlla, M. y Vázquez, N. (2010). Análisis Psicométrico de la adaptación argentina de la escala de Locus de Control de Rotter. 2, 133.

http://www.uca.edu.ar/uca/common/grupo68/files/Documento_de_Tr abajo_Locus_de_Control1.pdf

4. Bulut, N., Serin, O. y Şahin, S. (2010). Factors affecting the locus of control of the university students. Procedia Social and Behavioral Sciences, 2, 449-452. doi: 10.1016/j.sbspro.2010.03.041 
5. Camgoz, S. M., Tektas, O. O. y Metin, I. (2008). Academic attributional style, self-efficacy and gender: A cross-cultural comparison. Social Behavior and Personality: an international journal, 36(1), 97-114.

6. Durán-Aponte, E. y Pujol, L. (2012). Diferencias de género y área de estudio en las atribuciones causales de estudiantes universitarios. Anales de la Universidad Metropolitana, 12(2), 39-51.

7. Ferrando, P. J., Demestre, J., Anguiano-Carrasco, C. y Chico, E. (2011). Evaluación TRI de la escala I-E de Rotter: un nuevo enfoque y algunas consideraciones. Psicothema, 23(2), 282-288.

8. Hernández, R., Fernández, C. y Baptista, P. (2010). Metodología de la investigación. México: McGraw- Hill.

9. Lefcourt, H. M., Von Baeyer, C. L., Ware, E. E. y Cox, D. J. (1979). The multidimensional-multiattributional causality scale: The development of a goal specific locus of control scale. Canadian Journal of Behavioural Science/Revue canadienne des sciences du comportement, 11(4), 286.

10. Mayora-Pernia, C. A. y Fernández, N. (2015). Locus de control y rendimiento académico en educación universitaria: una revisión bibliográfica. Revista Electrónica Educare, 19(3), 1-23. doi: 10.15359/ree.19-3.16

11. Mayoral, L., Gangloff, B. y Romero, M. d. C. (2009). El locus de distribución como corolario del locus de control. Actualidades Investigativas en Educación, 9(2), 1-15.

12. Mkumbo, K. A. K. y Amani, J. (2012). Perceived university students' attributions of their academic success and failure. Asian Social Science, 8(7), 247-255. doi: 10.5539/ass.v8n7p247

13. Montes-Hidalgo, J. y Tomás-Sábado, J. (2016). Autoestima, resiliencia, locus de control y riesgo suicida en estudiantes de enfermería. Enfermería Clínica, 26(5). doi: 10.1016/j.enfcli.2016.03.002

14. Richardson, M., Abraham, C. y Bond, R. (2012). Psychological correlates of university students' academic performance: A sytematic review and meta-analysis. Psychological Bulletin, 138(2), 353-387. doi: 10.1037/a0026838

15. Rodríguez-Marín, J. y Inglés, C. J. (2011). Diferencias de sexo y curso en autoatribuciones académicas de estudiantes universitarios. Revista Mexicana de Psicología, 28(2), 173-181.

16. Sagone, E. y De Caroli, M. E. (2014). Locus of control and academic self-efficafy in universitary students: the effects of self-concepts. Social and Behavioral Sciences, 114, 222-228. doi: 10.1016/j.sbspro.2013.12.689 
17. Salvador, C. y Mayoral, L. (2011). Influencia de los estilos de atribución en la inteligencia emocional de los estudiantes argentinos. Revista Electrónica Interuniversitaria de Formación del Profesorado, 14(1), 243-251.

18. Sanjuán, P. y Magallares, A. (2006). Estilo atributivo negativo, sucesos vitales y sintomatología depresiva. Revista de psicopatología y psicología clínica, 11(2).

19. Suárez-Álvarez, J., Pedrosa, I., García-Cueto, E. y Muñiz, J. (2016). Locus of control revisited: development of a new bi-dimensional measure. Anales de psicología, 32(2), 578-586. doi: 10.6018/analesps.32.2.200781

20. Visdómine-Lozano, J. C. y Luciano, C. (2006). Locus de control y autorregulación conductual: revisiones conceptual y experimental. International Journal of Clinical and Health Psychology, 6(3), 729751.

21. Zaidi, I. H. y Mohsin, M. N. (2013). Locus of Control in Graduation Students. International Journal of Psychological Research, 6(1), 1520. 